\title{
Human Rights Implementation in the Means of Social Control on Lesbian Gay Biseksual Transgender (LGBT) in Indonesia
}

\author{
Desvia Winandra, Maria Eleonora Novena Pritasari and Silmina Azyyati \\ Faculty of Law, University of Tarumanagara, Indonesia \\ E-mail : desvia.winandra@gmail.com
}

\begin{abstract}
How to cite : Winandra, Desvia; Maria Eleonara Novena Pritasari; Silmina Azyyati. (2018). Human Right Implementation in the Means of Social Control on Lesbiam Gay Biseksual Transgender (LGBBT) in Indonesia . UNIFIKASI : Jurnal Ilmu Hukum, 5(2), 112-118. DOI : 10.25134/unifikasi.v5i2.1160 Submitted : 05-5-2018 Revised : 02-08-2018 Accepted : 29-08-2018
\end{abstract}

\begin{abstract}
Human rights applied in Indonesia do not conflict with Pancasila, the 1945 Constitution and religion, and are relative-particularistic. All citizens have the basic rights to freedom. However, the freedom they possess has limits that apply to all citizens without exception, including for lesbian, gay, bisexual, and transgender (LGBT) people. The purpose of this research is to analyze the treatment and views of the society and the implementation of human rights on lesbian, gay, bisexual, and transgender. The method used was non-doctrinal research method. The results of the research showed that the presence of LGBT people is still accepted, but their behavior is not acceptable in society. In conclusion, human right is basically the basic right that every human being has from the womb, born until his death and this right is irrevocable for any reason, except by the Almighty God as the Creator. Indonesia strictly forbids LGBT because it is not in accordance with Pancasila and contradicts with Indonesian cultural values. Yet, in Human Rights Law context, LGBT should get the same rights as other citizens. Human Rights Law in Indonesia protects all citizens' rights, without exception, especially their civil rights.
\end{abstract}

Keywords: Human rights; social control; LGBT

\section{Implementasi Hukum Hak Asasi Manusia dalam Sarana Kontrol Sosial terhadap Pelaku Lesbian Gay Biseksual Transgender (LGBT) di Indonesia}

\begin{abstract}
Abstrak : Hak Asasi Manusia (HAM) yang berlaku di Indonesia tidak bertentangan dengan Pancasila, Undang Undang Dasar 1945 dan agama, serta bersifat partikularistik relatif. Semua manusia memiliki hak asasi atas kebebasan. Namun, kebebasan yang dimiliki memiliki batas-batas yang berlaku bagi semua orang tanpa terkecuali, termasuk bagi kaum lesbian, gay, biseksual, transgender (LGBT). Tujuan penelitian ini yaitu merumuskan perlakuan dan pandangan masyarakat serta implementasi hukum hak asasi manusia terhadap lesbian, gay, biseksual, transgender. Metode penelitain yaitu mengunakan penelitian non doktrinal. Hasil dari penelitian yang diperoleh menyatakan bahwa kaum LGBT kehadirannya masih diterima tetapi perilaku mereka tidak dapat diterima di dalam masyarakat. Simpulan yaitu bahwa Pada dasarnya hak asasi manusia merupakan hak dasar yang dimiliki setiap manusia sejak dalam kandungan, lahir sampai kematiannya yang tidak dapat dicabut dengan alasan apapun juga kecuali oleh Tuhan Yang Maha Esa sebagai penciptanya. Indonesia melarang keras LGBT karena tidak sesuai dengan Pancasila dan bersimpangan dengan nilai budaya Indonesia, tetapi dalam konteks Hukum Hak Asasi Manusia, LGBT seharusnya mendapatkan hak yang sama dengan masyarakat lain. Hukum Hak Asasi Manusia di Indonesia melindungi seluruh hak masyarakatnya, tanpa terkecuali, terutama hak sipilnya.
\end{abstract}

Kata Kunci: Hak Asasi Manusi;, Kontrol Sosial; LGBT

\section{INTRODUCTION}

Basically, human right (HAM) is the basic right that every human being has from the womb, born until his death and this right is irrevocable for any reason, except by the Almighty God as the Creator. Human right is a crystallization of various value systems and philosophies about humans and all aspects of their lives. The main focus of human rights is human life and dignity. ${ }^{1}$

There are two views on human rights, namely human rights as universal rights and human rights as relative or particular rights. Human right as a universally applicable law is declared in the Declaration of Human Rights in 1948, while human right as a positive law is

\footnotetext{
1 Riyadi, Eko. 2018. Hukum Hak Asasi Manusia Perspektif Internasional, Regional dan Nasional. Cetakan Pertama. Jakarta: PT Raja Grafindo Persada. pp 25.
} 
applied Indonesia, as an addition to human rights contained in international documents, which considers the values existing in society. ${ }^{2}$

Based on Article 1 paragraph (1) of Law Number 39 of 1999 concerning Human Rights, Human Right (HAM) is defined as a set of rights inherent in the nature and existence of humans as beings of God Almighty and is a gift that should be respected, upheld and protected by the state, law, government, and everyone for the honor and protection of human dignity. ${ }^{3}$ From the definition, it can be concluded that human rights adopted in Indonesia are particularistic because human rights are defined as a gift from God that prioritizes the social values in society's life which is relative in nature.

Pancasila is the basis of the Republic of Indonesia so that all regulations in Indonesia are guided by Pancasila. Besides, Indonesia is also guided by the 1945 Constitution. Thus, Human rights applied in Indonesia should not conflict with the values in Pancasila and the 1945 Constitution.

Currently, human rights as particularism are being replaced by universal human rights because "in modern human rights concept, the influence of liberalism can be seen in passive civil rights, namely individual freedom from state interference". ${ }^{4}$

LGBT does not correspond to the image of Indonesian people so that its presence becomes a controversy and creates opposition. Many LGBT people are starting to openly show themselves. "The lesbian, gay, bisexual, and transgender (LGBT) phenomenon has become a widely discussed issue in Indonesian society with the rise of promotion or advertisement of LGBT on social media. Recruitment propaganda by LGBT people has been spread on various social media, even LGBT groups have also spread to campuses, schools and other public places" 5 .

In the 1945 Constitution (UUD 1945), freedom is regulated in the 1945 Constitution Amendment II, namely Article 28 E Paragraph

\footnotetext{
2 Kunto. Hak Asasi Manusia dan Polri. Jakarta: Cipta Manunggal,1997. pp 105-106.

${ }^{3}$ Indonesia, Undang-Undang Nomor 39 Tahun 1999 tentang Hak Asasi Manusia, Pasal 1

${ }^{4}$ Riyadi, Eko. 2018. Hukum Hak Asasi Manusia Perspektif Internasional, Regional dan Nasional. Cetakan Pertama. Jakarta: PT Raja Grafindo Persada. Pp. 32

5 Rustam Dahar Karnadi Apollo Harahap, “ LGBT Di Indonesia: Perspektif Hukum Islam, HAM, Psikologi dan Pendekatan Mașlaḥah “ dalam jurnal Al Hakam, Volume 26, Nomor 2, Oktober 2016.pp.34-43.
}

(2) which states that every person has the right to freedom of belief, expressing thoughts and attitudes in accordance with his conscience. ${ }^{6}$ This regulation has become one of the factors supporting Indonesian citizens to be lesbian, gay, bisexual and transgender.

However, this view is wrong because even if a person is given the right to freedom, the freedom is regulated in law and the contents should not conflict with the values of Pancasila and religion.

Human rights and human beings are two things that cannot be separated. Human rights do not look at someone's race, ethnicity, religion, and gender so that even if the person is gay, lesbian, bisexual or transgender, he still has the same rights as the others. The rights listed in the Act also apply to transgender people. For example, Article 28 A of the 1945 Constitution states that everyone has the right to live and has the right to defend his life so that even if the person is an LGBT, his right to live should be protected. ${ }^{7}$ In addition, Article $28 \mathrm{~J}$ paragraph (1) of the 1945 Constitution states that humans have the right to live, the right not to be tortured, the right to freedom of thought and conscience, the right to be recognized as a person before the law, and the right not to be prosecuted on the basis of law.

One of the contents of the Hensilki Final Act of 1975 is equality and the right to determine oneself. Then, in the Yogyakarta Principles, it is stated that "sexual orientation refers to one's capacity to bring emotional, sexual and feelings of interest to others, as well as intimate and sexual relations to other people of different gender or same or more than one types of gender". ${ }^{8}$ In France Constitution, it was then added and expanded in 1793 and 1848 as well as in the constitution of 1793 and 1795 . This revolution was initiated by great thinkers, such as J.J. Rousseau, Voltaire, and Montesquieu. The human rights concluded in the declaration include: ${ }^{9}$

1. Humans are born independent and remain independent.

2. Humans have the same rights.

\footnotetext{
${ }^{6}$ UUD 1945 Amandemen II Pasal 28 E tentang Hak Asasi Manusia

7 UUD 1945 Amandemen II Pasal 28 J tentang Hak Asasi Manusia

${ }_{9}^{8}$ Alkatiri, Zefri. Belajar Memahami HAM, pp. 38

9 Asmini, Yuli dkk. 2015 .The Yogyakarta Principles, PrinsipPrinsip Pemberlakuan Hukum HAM Internasional dalam Kaitannya dengan Orientasi Seksual dan Identitas Gender. Jakarta: Komnas HAM..pp.ix.
} 
3. Humans are free to do something without harming others.

4. Humans are free to decide their religion and belief.

5. Humans are free to express their views.

These international documents become the basis for the development of LGBT in Europe, which later become the basis for the development of LGBT in Indonesia. As an adherent of relative-particularistic human rights, Indonesia opposes LGBT, but the absence of regulations governing LGBT makes LGBT cannot be legally prohibited.

The development of lesbian, gay, bisexual, and transgender people raises the pros and cons of various circles in Indonesia, many of them think that it is something that deviates from the personality of Indonesian nation.

As a legal citizen, lesbian, gay, bisexual, and transgender people have rights that should be recognized by the government. Yet, what they want is not what they get. LGBT people often experience sexual discrimination as well as being underestimated and even considered inappropriate to live in the midst of society by some people who claim to be anti LGBT because they are not in accordance with moral and religious values.

This refusal makes LGBT people feel that their basic rights are disturbed and obstructed. The regulations made by certain agencies that refuse LGBT workers and community leaders who have protested against the presence of LGBT people as well as scorn from the community make LGBT people feel that their position is threatened in their own country. Even though they should have the right to be free from torture or cruel, inhumane treatment, and humiliation of their level and human dignity.

In the name of human rights, LGBT perpetrators, adherents, and victims demand the government to abolish sexual discrimination against gender identity and fulfill their basic rights. By looking at the reality, LGBT people often get different treatment from others, such as in education and employment, since there are certain conditions that cannot be fulfilled by LGBT people. This is what LGBT demands on the government regarding their basic rights as citizens.

In western countries, such as Mexico, Portugal, England and others, LGBT is a common thing because it is legalized. Yet, it is different from Indonesia where LGBT is taboo because it clearly deviates from Pancasila which is the basis of the state. A few people even assume that LGBT is a disease that can cause human extinction and destroy the nature of family and human.

In Indonesia, there are several cases regarding LGBT. One of the cases that has been widely discussed and highlighted by foreign media is the gay party held on Sunday, May 21, 2017 in Kelapa Gading area, North Jakarta. The police spokesman, Agus Yuwono, confirms that 141 people including the owner and several perpetrators have been arrested for questioning and sentenced under the pornography law applied in Indonesia. ${ }^{10}$

For the majority of the people, the incident is a disgrace that needs to be immediately addressed and become a serious problem for the country. Yet, on the other hand, they still have the right to be protected as legal citizens. Thus, regarding the background described above, the problem discussed in this research is formulated into the following questions:

1. What are the treatment and view of the society towards transgender bisexual lesbian gay (LGBT) in Indonesia?

2. How is the implementation of human rights law as a means of social control over transgender bisexual lesbian gay (LGBT) in Indonesia?

\section{METHOD}

The research method used by the author is a non-doctrinal research method. The data used in this study is secondary data, namely primary legal material starting from the 1945 Constitution, secondary legal material in the form of journals, theses, previous studies and relevant references.

\section{RESULTS AND DISCUSSION \\ The treatment and view of the society towards LGBT in Indonesia}

Article 28A to Article 28J of the 1945 Constitution concerning Human Rights and Law Number 39 of 1999 concerning Human Rights regulate human rights that apply to all citizens regardless of race, ethnicity and religion as stated in Law Number 38 of 1999 Article 33 paragraph (1) that "Everyone has the

\footnotetext{
${ }^{10}$ The Guardian, Indonesian Police Arrest More than 140 Men at Alleged Gay Sauna Party. Accsessed on 15 April 2018
} 
right to be free from torture, punishment or cruel, inhumane treatment, and humiliation of his level and human dignity". ${ }^{11}$ If viewed from the perspective of positive law in Indonesia, LGBT people are also humans who have an identity with a National Identity Card as a legal citizen in Indonesia. This shows that they should get legal protection and have the same rights before the law.

However, in relation to the fulfillment of these rights, the Act is also used as a tool in determining the limitations of human rights in Indonesia. As stated in Article 28J paragraph (2) of the 1945 Constitution that in applying their rights and freedoms, everyone is obliged to be obedient to the limitations set by the Act with the purpose of guaranteeing recognition and respect for other people's rights and freedoms and fulfilling the demands in accordance with moral values, religious values, security, and public orderliness in a democratic society. This article clearly shows that Indonesian nation adheres to a particularisticrelative view of human rights in which there are limitations in obtaining human rights in accordance with the religious and cultural values that live in society.

In reality, the presence of LGBT people is still accepted to live in the midst of society, only their behavior that makes people think that they do not deserve to live in the midst of society. The acceptance or the refusal of LGBT perpetrators, victims, and adherents and their behavior is still a polemic in society. It is proved by a survey conducted by Saiful Mujani Research Center (SMRC) on December 2017 which shows that: ${ }^{12}$

a. 58.3\% of respondents have heard about LGBT.

b. Of the respondents who know about LGBT, $41.4 \%$ feel that LGBT is very threatening; $46.2 \%$ feel quite threatening; $9.4 \%$ feel non-threatening; $1.4 \%$ feel very nonthreatening; and $1.6 \%$ do not know/do not answer.

c. $34 \%$ of the respondents strongly agree that gay and lesbian are prohibited by religion; $47.5 \%$ agree; $4.7 \%$ disagree; $3.9 \%$ strongly disagree; and $9.9 \%$ do not answer/ do not know.

\footnotetext{
${ }^{11}$ UUD 1945, Undang - Undang Nomor 38 Tahun 1999 Pasal 33

${ }^{12}$ Anonim, "Survei SMRC 41 Persen Warga Indonesia Tolak Hak Hidup LGBT". www.tirto.id, 25 Januari 2018.
}

From the data, it can be seen that the majority of the society refuse LGBT. However, $57 \%$ of the respondents state that LGBT has the right to live. Thus, although the majority of the respondents reject LGBT, they also recognize the right to live for LGBT.

According to the results of a research from the Ministry of Women's Empowerment and Child Protection at Health Research Center of the University of Indonesia, it is stated that "People have an initial impression of LGBT as contagious and some other informants see LGBT as a deviation. Other informants see LGBT as a social disease because it contradicts or violates the religious norms and values adopted by the majority of people in Indonesia. There are also informants who see LGBT as a group of people who are different from people in general. Yet, they cannot express it because it is limited by environmental rules. Informants who refuse the existence of LGBT argue that they are contrary to religious values. For informants who refuse LGBT, they tend to criticize or isolate the presence of LGBT. In contrast, informants who accept the presence of LGBT argue that at this time, the society has had sufficient knowledge and understanding of LGBT so that they do not discriminate against LGBT. The majority of informants, although they are not comfortable with the presence of LGBT, do not complicate it as long as they can behave well in the community." 13

There are several views on human rights law in Indonesia concerning LGBT, as follows:

1. According to the Indonesian Council of Ulama (MUI), "The argument is clear that LGBT people want to be recognized, accepted, and respected as a free community, while the noble values, culture and life view of the nation are marginalized in the name of human rights." 14

2. According to Allan Fatchan Gani Wardhana , "First, if we look at Article (1) of Law Number 39 of 1999 concerning Human Rights, Human Right is a gift from God and it is the rights that humans have solely because they are human. Then, the

\footnotetext{
13 Damayanti, Rita. 2015. "Pandangan Masyarakat terhadap Lesbian, Gay, Biseksual dan Transgender (LGBT) di Jakarta, Bogor , Depok dan Tangerang”. Dalam Laporan Kajian Kementrian Pemberdayaan Perempuan dan Perlindungan Anak Anak Pusat Penelitian Kesehatan Universitas Indonesia. pp 26. www.kemenpppa.go.id

14 Gani, Allan Fatchan. 2016. "LGBT, HAM \& Pandangan Hidup Bangsa”. Dalam Kompasiana. 20 Februari. pp 1.
} 
principles of humanity and deity apply. The grace of God that creates people in pairs with the opposite sex has become a standard in any religion. Thus, if we like people with the same sex, we clearly insult His grace and violate the nature of humanity. Besides, in Indonesia, the human rights applied are not individual human rights which only protect personal or one group's interests, but they are communal human rights which protect the wider community interests. The accent point is communal human rights, not individuals. We cannot equate our human rights concepts with western human rights or the rights of other countries. If we look at Article 28J paragraph (2), moral considerations, religious values, and public orderliness should be the basis for prohibiting propaganda and LGBT legality efforts." 15 "Secondly, LGBT is not only about human rights issues, but it also about the noble values, culture and view of the nation. Bringing the LGBT debate only into a human rights issue will only lead to a flawed and incomplete analysis." 16 "Thirdly, in living in a community, nation and state, Pancasila has been agreed upon and in the end, the people rely on Pancasila. By looking at history, Pancasila is formulated as a dynamic consensus as well as a guiding star which leads the nation in achieving its goals. However, the existence of LGBT phenomenon is in contradiction to Pancasila meaning that it is contrary to the culture, noble values, and the life view of the nation. Yet, the State should treat LGBT people fairly because they are citizens who have the right to be protected from violence and oppression. In addition, by continuing to treat LGBT people fairly is also in accordance with the word of God and do not make hatred on an unfair behavior."17

\section{The role of human rights law as social control in Indonesia}

To meet the society's needs, there is a need to formulate law as a social control of the society which is then interpreted as a supervisor by the society towards government's

\footnotetext{
${ }^{15}$ Ibid., pp 1

${ }^{16}$ Ibid., pp 1.

${ }^{17}$ Ibid., pp. 1
}

administration. Thus, social control aims to achieve harmony between stability and change in society. From its nature, social control is preventive or repressive. Preventive is an effort to prevent disturbances in certainty and justice, while repressive efforts aim to restore the harmony between legal with society. The process of social control can be carried out without violence or coercive. ${ }^{18}$

According to Roscou Pound's theory, social control is needed to strengthen the civilization of human society because it controls anti-social behavior which contradicts to the rules of social order. The law, as a social control mechanism, is the main function of the state and works through the application of forces carried out systematically and regularly by the agents appointed to perform that function. However, Pound adds that law is not enough. It needs support from family, education, morals, and religion. Law is a teaching system with ideal and empirical elements which combines natural law and positivistic theory. ${ }^{19}$ Roscoe Pound is the first legal expert to analyze jurisprudence and social sciences methodology.

According to Soerjono Soekanto's theory, law as a tool or means of social control can be used as an agent of change. As an agent of change, leader has gained the trust from the society to lead them in changing the social system in carrying out the things related to changes in social institutions. This desired social change is under legal control and supervision as an agent of change.

As a social control, law has a role to control the society's behavior, especially in fulfilling their rights and obligations. In fulfilling these rights, not all rights can be fulfilled since there are certain rules that limit those rights. If we look at LGBT issue that is widely discussed, the law has not really become an agent of change because the law itself has not followed the society's development.

As a means of social control, law has the duty to keep the community in the accepted patterns of behavior. Law can be seen as a formal juridical activity. In this view, it is seen as an activity to formulate in an orderly manner

\footnotetext{
${ }^{18}$ Iriani, Dewi. "Hukum Sebagai Alat Kontrol Sosial dan Sistem Supremasi Penegakan Hukum"

19 Lathif, Nazaruddin. "Teori Hukum Sebagai Sarana atau Alat Untuk Memperbaharui atau Merekayasa Masyarakat". (Pakuan : FH Pakuan, 2017), pp. 77.
} 
according to a predetermined procedure and the society's will. $^{20}$

In Article 292 of the Criminal Code (KUHP), it is stated that adults who commit obscene acts with other people of the same sex, who they know or should be supposed to be immature, are threatened with a maximum imprisonment of five years. This regulation proves that same-sex relationships are prohibited in law and can even be subject to criminal acts. $^{21}$

National Commission on Human Rights (Komnas HAM), Natalius Pigai, says that the state has an obligation to protect Indonesian citizens regardless of type, ethnicity, religion, race, or minority groups and vulnerable groups (meaning vulnerable to violence). The state has an obligation to fulfill human rights of all Indonesian citizens regardless of ethnicity, religion, including minorities and vulnerable groups as well as LGBT. $^{22}$ Although LGBT is not legalized in Indonesia, LGBT people's rights in Indonesia should be protected, there are even regulations regarding the protection of the rights. "The protection that should be guaranteed and given in this LGBT context from a human rights perspective is the protection of their human rights in the form of health insurance to be able to recover from the disease, as declared in Article 25 of Human Rights Document (DUNHAM)". ${ }^{23}$

Thus, it can be concluded that LGBT people need to get their human rights in the form of guarantee of care or treatment of the LGBT disease. It is not about recognizing or legalizing their deviant sexual orientation. On the other hand, in addition to human rights of LGBT people, there is also Human Rights Obligations (KAM) that should be obeyed by everyone as stated in Article 29 paragraph (1 and 2) of DUNHAM, namely: (1) Everyone has an obligation to the society where he can develop his personality freely and fully; and (2) In applying their rights and freedoms, everyone should be obedient to the limitations set by the law which aims to guarantee the recognition and respect for others' rights and freedoms and

${ }^{20}$ Rahardjo, Satjipto. Hukum dan Masyarakat, pp.117

${ }^{21}$ Kitab Undang-Undang Hukum Pidana Pasal 292

${ }^{22}$ Pigai, Natalius. "LGBT Marak, Apa Sikap Kita?" dalam diskusi Indonesian Lawyer's Club (ILC) di TV.ONE, 16 Februari, 2016.

${ }^{23}$ Harahap, Rustam Dahar Karnadi Apollo. "LGBT Di Indonesia: Perspektif Hukum Islam, HAM, Psikologi dan Pendekatan Maṣlaḥah “ dalam jurnal Al Hakam, Volume 26, Nomor 2, Oktober 2016 to fulfill fair conditions in terms of decency, order and general welfare in a democratic society. ${ }^{24}$ Basic obligations owned by someone (including LGBT people), as a form of respect for other people's rights which can also be interpreted as a limitation on a person's human rights, should be determined based on law as regulated in Article 70 and 73 of Law Number 39 of $1999 .^{25}$

\section{CONCLUSION}

Based on the discussion, it can be concluded that human right is basically the basic right that every human being has from the womb, born until his death and this right is irrevocable for any reason, except by the Almighty God as the Creator. The human rights adopted in Indonesia are particularistic because human rights are attached as a gift from God that prioritizes the social values in society's life which is relative in nature.

Human rights in Indonesia apply universally to all citizens, regardless of social and economic status and gender. Today, LGBT case in Indonesia is being opposed by the society. LGBT people get improper treatment even some of their rights must be seized. Besides, there are also various forms of discrimination that make LGBT people have difficulty in living their lives. If viewed from a human rights perspective as relativeparticularistic, it is clear that Indonesia strictly forbids LGBT because it is not in accordance with Pancasila and contradicts with Indonesian cultural values. Yet, in Human Rights Law context, LGBT should get the same rights as other citizens. Human Rights Law in Indonesia protects all citizens' rights, without exception, especially their civil rights.

\section{SUGGESTION}

Based on these conclusions, it is clear that the role of government and society has a great effect in overcoming LGBT cases in Indonesia. Society, as the biggest component that surrounds the perpetrators or adherents of LGBT, should embrace them to recognize and be obedient to the basis of the state namely Pancasila and the moral values contained therein, and do not isolate and make them feel depressed. Meanwhile, the role of the

\footnotetext{
${ }^{24}$ Ibid., pp. 236

${ }^{25}$ UU No. 39 Pasal 70 dan 73
} 
government is to provide rehabilitation centers for lesbian, gay, bisexual, and transgender (LGBT) people. It is because, medically, LGBT is a disease that can still be cured by rehabilitation, like drug rehabilitation centers. If the perpetrator has passed his rehabilitation period, he is returned to the society to be able to carry out their social functions in a society. In addition, the role of the community is also needed to receive them back into society. Poor people's view of them will only make them feel isolated and deviate from cultural, religious and norms values in that society. Therefore, a strong cooperation between government and society is needed to fight LGBT.

\section{Books}

\section{REFERENCES}

Alkatiri, Zefry. (2010). Belajar Memahami HAM. Cetakan Pertama. (Jakarta: Ruas, 2010)

Asmini, Yuli dkk. (2015) .The Yogyakarta Principles, Prinsip-Prinsip Pemberlakuan Hukum HAM Internasional dalam Kaitannya dengan Orientasi Seksual dan Identitas Gender. Jakarta: Komnas HAM.

Lathif, Nazaruddin. (2017). Teori Hukum Sebagai Sarana atau Alat Untuk Memperbaharui atau Merekayasa Masyarakat. (Pakuan : FH Pakuan, 2017).

Qamar, Nurul dkk. (2016). Sosiologi Hukum (Sociology of Law). Jakarta: Penerbit Mitra Wacana Media.

Rahardjo, Satjipto. 1980. Hukum dan Masyarakat. Bandung: Penerbit Angkasa.

Riyadi, Eko. (2018). Hukum Hak Asasi Manusia Perspektif Internasional, Regional dan Nasional. Cetakan Pertama. Jakarta: PT Raja Grafindo Persada.

Soekanto, Soerjono. (1982). Pengantar Sosiologi Hukum. Cetakan ke-2. Jakarta: CV Rajawali.

Soekanto, Soerjono. (2014). Pokok-Pokok Sosiologi Hukum. Cetakan ke-23. Depok: PT Rajagrafindo Persada.

Soekanto, Soerjono dan Mustafa Abdullah. (1982). Sosiologi Hukum dalam Masyarakat. Cetakan ke-1 . Jakarta: CV Rajawali

\section{Legislations}

Republik Indonesia, Undang Undang Dasar 1945

Kitab Undang-Undang Hukum Pidana (KUHP)

Republik Indonesia, Undang-undang Nomor 39 Tahun 1999 tentang Hak Asasi Manusia

Papers, Scientific Journals, Articles, and Dictionaries

Anonim, "Survei SMRC 41 Persen Warga Indonesia Tolak Hak Hidup LGBT". www.tirto.id, 25 Januari 2018.

Budiman, Haris. (2017). "Pelanggaran Hak Asasi Manusia dalam Kebijakan Daerah di Bidang Tata Ruang di Kabupaten Kuningan". Dalam Jurnal Unifikasi, 1 Januari.

Damayanti, Rita. (2015). "Pandangan Masyarakat terhadap Lesbian, Gay, Biseksual dan Transgender (LGBT) di Jakarta, Bogor, Depok dan Tangerang". Dalam Laporan Kajian Kementrian Pemberdayaan Perempuan dan Perlindungan Anak Anak Pusat Penelitian Kesehatan Universitas Indonesia.

Gani, Allan Fatchan. (2016). "LGBT, HAM \& Pandangan Hidup Bangsa". Dalam Kompasiana. 20 Februari.

Harahap, Rustam Dahar Karnadi Apollo. (2006). "LGBT di Indonesia: Perspektif Hukum Islam, HAM, Psikologi dan Pendekatan Mașlaḥah". Dalam Jurnal: $A L$-AHKAM Volume 26, Nomor 2, Oktober 2016.

Iriani, Dewi. (2011) "Hukum Sebagai Alat Kontrol Sosial dan Sistem Supremasi Penegakan Hukum". Justicia Islamica: Jurnal Kajian Hukum dan Sosial. 8(1). Pp.139-149.

Katumiri. (2016). "Diskriminasi Kaum LGBT di Jakarta". Dalam Jurnal Suara Kita. 21 Desember.

Octaviani, Zahrotul. (2018). "Pasal tentang LGBT di RUU KUHP sedang Dibahas DPR". Dalam Republika. 21 Januari, Jakarta.

Pigai, Natalius. (2018) "LGBT Marak, Apa Sikap Kita?" dalam diskusi Indonesian Lawyer's Club (ILC) di TV.ONE, 16 Februari, 2016.

Santoso, Meillany Budiarti. (2016). LGBT dalam Perspektif Hak Asasi Manusia. (Share: Social Work Jurnal. 6(2).pp.220229. 